\title{
Apigenin and luteolin modulate microglial activation via inhibition of STATI-induced CD40 expression
}

\author{
Kavon Rezai-Zadeh ${ }^{\dagger 1}$, Jared Ehrhart ${ }^{\dagger 1}$, Yun Bai ${ }^{1}$, Paul R Sanberg², \\ Paula Bickford ${ }^{2,3}$, Jun Tan ${ }^{1,2}$ and R Douglas Shytle*1,2
}

\author{
Address: ${ }^{1}$ Silver Child Development Center, Department of Psychiatry and Behavioral Medicine, College of Medicine, University of South Florida, \\ Tampa, FL 33612, USA, ${ }^{2}$ Center Excellence in Aging and Brain Repair, Department of Neurosurgery, College of Medicine, University of South \\ Florida, Tampa, FL 33612, USA and 'James A. Haley Veterans' Hospital, Tampa, Fl 33612, USA \\ Email: Kavon Rezai-Zadeh - krezaiza@health.usf.edu; Jared Ehrhart - jehrhar1@health.usf.edu; Yun Bai - ybai1@health.usf.edu; \\ Paul R Sanberg - psanberg@health.usf.edu; Paula Bickford - pbickfor@health.usf.edu; Jun Tan - jtan@health.usf.edu; R \\ Douglas Shytle* - dshytle@health.usf.edu \\ * Corresponding author †Equal contributors
}

Published: 25 September 2008

Journal of Neuroinflammation 2008, 5:41 doi:10.1186/1742-2094-5-4I
Received: 16 January 2008

Accepted: 25 September 2008

This article is available from: http://www.jneuroinflammation.com/content/5/I/4I

(c) 2008 Rezai-Zadeh et al; licensee BioMed Central Ltd.

This is an Open Access article distributed under the terms of the Creative Commons Attribution License (http://creativecommons.org/licenses/by/2.0), which permits unrestricted use, distribution, and reproduction in any medium, provided the original work is properly cited.

\begin{abstract}
Background: It is well known that most neurodegenerative diseases are associated with microglia-mediated inflammation. Our previous research demonstrates that the CD40 signaling is critically involved in microglia-related immune responses in the brain. For example, it is well known that the activation of the signal transducer and activator of transcription (STAT) signaling pathway plays a central role in interferon-gamma (IFN- $\gamma$ )-induced microglial CD40 expression. We and others have previously reported that microglial CD40 expression is significantly induced by IFN- $\gamma$ and amyloid- $\beta$ (A $\beta$ ) peptide. Recent studies have shown that certain flavonoids possess antiinflammatory and neuroprotective properties distinct from their well-known anti-oxidant effects. In particular, flavonoids, apigenin and luteolin have been found to be effective CD40 immunomodulators.
\end{abstract}

Methods: Cultured microglia, both N9 and primary derived lines, were treated with flavonoids in the presence of IFN- $\gamma$ and/or CD40 ligation to assess any anti-inflammatory effects and/or mechanisms. CD40 expression on microglia was analyzed by fluorescence activated cell sorting (FACS). Anti-inflammatory effects and mechanisms were confirmed by ELISA for interlekin-6 (IL6) and TNF- $\alpha$, lactate dehydrogenase (LDH) assay, and STATI Western blotting.

Results: Apigenin and luteolin concentration-dependently suppressed IFN- $\gamma$-induced CD40 expression. Apigenin and luteolin also suppressed microglial TNF- $\alpha$ and IL- 6 production stimulated by IFN-gamma challenge in the presence of CD40 ligation. In addition, apigenin and luteolin markedly inhibited IFN- $\gamma$-induced phosphorylation of STATI with little impact on cell survival.

Conclusion: Our findings provide further support for apigenin and luteolin's anti-inflammatory effects and suggest that these flavonoids may have neuroprotective/disease-modifying properties in various neurodegenerative disorders, including Alzheimer's disease $(A D)$. 


\section{Background}

Multiple lines of evidence suggest microglia, the resident immune cells of the central nervous system (CNS), play a critical role in the etiology of various neurodegenerative diseases. Chronic activation of microglia is believed to trigger and maintain an inflammatory response, which may ultimately lead to neuronal cell death such as that observed in Alzheimer's disease (AD), HIV-dementia, Parkinson's disease, prion disease, amyotrophic lateral sclerosis, and multiple sclerosis [1-11]. In fact, this chronic activation exposes the CNS to elevated levels of a wide array of potentially neurotoxic molecules including proinflammatory cytokines, complement proteins, proteinases, and reactive oxygen species (ROS) [12-17]. Conversely, an alternative view suggests that dysregulation of microglial activation may prevent appropriate immune responses necessary to respond to neuroinsults [18]. Essential to microglial activation is the stimulatory signal from CD40 ligation. CD40 and its ligand (CD40L) are key immunoregulatory molecules that provide co-stimulatory input to cells from both the innate and adaptive arms of the immune system [19-22]. The classical stimulatory signal for microglial activation is propagated by T-cell release of interferon-gamma (IFN- $\gamma$ ), which consequently sensitizes the microglia by upregulating the expression of various immunoregulatory molecules, including CD40, on their cell surfaces $[23,24]$. Furthermore, it is well known that the activation of the Janus kinase/signal transducer and activator of transcription (JAK/STAT) signaling pathway plays a central role in this IFN- $\gamma$-induced microglial CD40 expression $[25,26]$. We have previously reported that microglial CD40 expression is significantly increased by IFN- $\gamma$ in the presence of $\beta$-amyloid (A $\beta$ ) peptide via STAT1 activation $[27,28]$. Accordingly, modulation of the JAK/STAT signaling pathway may not only prove to be an effective means for suppressing microglial-mediated inflammation but also an important target for neurodegenerative disease therapy.

While several anti-inflammatory drugs have been found to prevent microglial-mediated inflammation, their underlying mechanisms remain unclear and the search for more effective practical compounds continues. Recent research has focused on the analysis of flavonoids, which epidemiological study suggest are beneficial against the neurodegeneration and aging processes [29-33]. Flavonoids, a group of phenolic phytochemicals, are common in vascular plants and are abundant in particular spices, vegetables, and fruits. They are considered important constituents in the human diet, although their daily intake varies with dietary habits $[34,35]$. Several medicinal properties have been ascribed to flavonoids, notably anti-oxidant [36,37], anti-carcinogenic [38,39], and antiinflammatory activity [40-42]. One such flavonoid, apigenin, and its phase I metabolite, luteolin, have been found to reduce CD40 and CD40L expression on dendritic cells and basophils, respectively $[43,44]$. Previous research has also shown apigenin's ability to inhibit proinflammatory cytokines production by monocytes, macrophages, and microglia and further substantiates this compound as versatile immunomodulator [45-49].

In the present study, we investigate the potential antiinflammatory effects and mechanisms of these flavonoids, apigenin and luteolin, in cultured microglia. Our findings demonstrate that treatment of both N9 and murine-derived primary microglia cell lines with apigenin and luteolin significantly reduces CD40 expression induced by IFN- $\gamma$. This reduction is paralleled by significant decreases in the release of the pro-inflammatory cytokines interleukin- 6 (IL-6) and tumor necrosis factor- $\alpha$ (TNF- $\alpha$ ) by the microglia. Furthermore, data show that apigenin and luteolin treatments achieve these reductions through inactivation of STAT1 and suggest a mechanism whereby these compounds may prove to be an effective therapy for neurodegeneration.

\section{Methods}

\section{Animals and microglial cell cultures}

Breeding pairs of BALB/c mice were purchased from Jackson Laboratory (Bar Harbor, ME) and housed in the animal facility at the University of South Florida, College of Medicine. Murine primary culture microglia were isolated from mouse cerebral cortices and grown in RPMI 1640 medium supplemented with 5\% FCS, $2 \mathrm{mM}$ glutamine, $100 \mathrm{U} / \mathrm{ml}$ penicillin, $0.1 \mu \mathrm{g} / \mathrm{ml}$ streptomycin, and 0.05 $\mathrm{mM}$ 2-mercaptoethanol according to previously described methods [50]. Briefly, cerebral cortices from newborn mice (1-2 day-old) were isolated under sterile conditions and were kept at $4{ }^{\circ} \mathrm{C}$ before mechanical dissociation. Cells were plated in $75 \mathrm{~cm}^{2}$ flasks and complete medium was added. Primary cultures were kept for 14 days so that only glial cells remained and microglial cells were isolated by shaking flasks at $200 \mathrm{rpm}$ in a Lab-Line incubatorshaker. More than $98 \%$ of these glial cells stained positive for microglial marker Mac-1 (CD11b/CD18; Boehringer Mannheim, Indianapolis, IN; data not shown). All animal protocols were approved by the Committee of Animal Research at the University of South Florida, in accordance with the National Institutes of Health guidelines. N9 microglial originally generated from myc-immortalized mice were cultured as previously described [50,51]. Briefly, N9 microglial cells were maintained and plated in $75 \mathrm{~cm}^{2}$ flasks with MEM medium supplemented with 5\% FCS and $2 \mathrm{mM}$ glutamine.

\section{Flow cytometric analysis of microglial CD40 expression}

Primary cultured microglial cells were plated in 6-well tissue culture plates at $5 \times 10^{5} \mathrm{cells} /$ well and incubated with apigenin and luteolin at different doses in the presence or 
absence of IFN- $\gamma(100 \mathrm{U} / \mathrm{ml})$. Eight hours after incubation, these microglial cells were washed with flow buffer [PBS containing $0.1 \%(\mathrm{w} / \mathrm{v})$ sodium azide and $2 \%(\mathrm{v} / \mathrm{v})$ FCS] and re-suspended in $250 \mu \mathrm{l}$ of ice-cold flow buffer for fluorescence activated cell sorting (FACS) analysis, according to methods described previously [50]. Briefly, cells were pre-incubated with anti-mouse CD16/CD32 monoclonal antibody (clone 2.4G2, PharMingen, Los Angeles, CA) for $10 \mathrm{~min}$ at $4^{\circ} \mathrm{C}$ to block non-specific binding to Fc receptors. Cells were then spun down at 5,000 g washed 3 times with flow buffer and then incubated with hamster anti-mouse CD40-FITC or isotype control antibody-FITC (1:100 dilution; PharMingen) in flow buffer. After $30 \mathrm{~min}$ incubation at room temperature, cells were washed twice with flow buffer, re-suspended in $250 \mu \mathrm{L}$ of flow buffer and analyzed by a FACScan ${ }^{\mathrm{TM}}$ instrument (Becton Dickinson, Franklin Lanes, NJ). A minimum of 10,000 cells were accepted for FACS analysis. Cells were gated based on morphological characteristics such that apoptotic and necrotic cells were not accepted for FACS analysis using CellQuest ${ }^{\mathrm{TM}}$ software (Beckton Dickinson). Percentages of positive cells (i.e. CD40expressing) were calculated as follows: for each treatment, the mean fluorescence value for the isotype-matched control antibody was subtracted from the mean fluorescence value for the CD40-specific antibody.

\section{TNF- $\alpha$, IL-6, and LDH analyses}

Murine primary cultured microglial cells were plated in 24-well tissue-culture plates (Costar, Cambridge, MA) at 1 $\times 10^{5}$ cells per well and stimulated for $12 \mathrm{hr}$ with either IFN- $\gamma(100 \mathrm{U} / \mathrm{ml}) / \mathrm{CD} 40$ agonistic antibody $(2 \mu \mathrm{g} / \mathrm{ml})$ (R\&D Systems, Minneapolis, MN) in the presence or absence of apigenin and luteolin at a range of concentrations. Cell-free supernatants were collected and stored at $70^{\circ} \mathrm{C}$ until analysis. TNF- $\alpha$ and IL- 6 levels in the supernatants were examined using ELISA kits (R\&D Systems) in strict accordance with the manufacturers' protocols. Cell lysates were also prepared and the BCA protein assay (Pierce Biotechnology, Rockford, IL) was performed to measure total cellular protein. Results are shown as mean pg of TNF- $\alpha$ or IL- 6 per mg of total cellular protein (+/$\mathrm{SD})$. Cell death was measured from lactate dehydrogenase (LDH) release in the cell-free supernatants using a CytoTox $96^{\circledR}$ Non-Radioactive Cytotoxicity Assay kit (Promega, Madison, WI).

\section{STATI signaling pathway analysis}

Primary culture microglial cells were plated in 6-well tissue culture plates at a density of $5 \times 10^{5}$ cells per well and co-incubated with IFN- $\gamma(100 \mathrm{U} / \mathrm{mL})$ in the presence or absence of a dose range of apigenin or luteolin for $30 \mathrm{~min}$. At the end of the treatment period, microglial cells were washed in ice-cold PBS three times and lysed in ice-cold lysis buffer. After incubation for 30 min on ice, samples were centrifuged at high speed for $15 \mathrm{~min}$, and supernatants were collected. Total protein content was estimated using the BCA protein assay (Pierce Biotechnology). Aliquots corresponding to $100 \mu \mathrm{g}$ of total protein was electrophoretically separated using $10 \%$ Tris gels. Electrophoresed proteins were then transferred to PVDF membranes (Bio-Rad, Richmond, CA), washed in $\mathrm{dH}_{2} \mathrm{O}$, and blocked for 1 hour at ambient temperature in TBS containing 5\% (w/v) non-fat dry milk. After blocking, membranes were hybridized for $1 \mathrm{~h}$ at ambient temperature with various primary antibodies. Membranes were then washed $3 \times$ for 5 min each in $\mathrm{dH}_{2} \mathrm{O}$ and incubated for 1 hour at ambient temperature with the appropriate HRP-conjugated secondary antibody $(1: 1,000$, Pierce Biotechnology). All antibodies were diluted in TBS containing $5 \%(\mathrm{w} / \mathrm{v})$ of non-fat dry milk. Blots were developed using the luminol reagent (Pierce Biotechnology). Densitometric analysis was conducted using a FluorS Multiimager with Quantity One ${ }^{\mathrm{TM}}$ software (BioRad, Hercules, CA). For STAT1 phosphorylation, membranes were probed with a phospho-Ser727 STAT1 antibody or a phospho-Tyr701 STAT1 antibody (Cell Signaling Technology, Danvers, MA) and stripped with stripping solution and then re-probed with antibody that recognize total STAT1 (Cell Signaling Technology).

\section{Statistical analysis}

All data were normally distributed; therefore, in instances of single mean comparisons, Levene's test for equality of variances followed by $t$-test for independent samples was used to assess significance. In instances of multiple mean comparisons, analysis of variance (ANOVA) was used, followed by post-hoc comparison using Bonferonni's method. Alpha levels were set at 0.05 for all analyses. The statistical package for the social sciences release 10.0.5 (SPSS Inc., Chicago, IL, USA) was used for all data analysis.

\section{Results}

\section{Apigenin and luteolin suppress IFN- $\gamma$-induced CD40 expression in N9 and murine-derived primary microglial cells}

To examine the effect apigenin and luteolin had on microglial activation via CD40, we initially treated N9 microglia cells over a range of concentrations. Following FACS analysis, we found that both compounds significantly reduced CD40 expression on the microglial cell surface $(\mathrm{p}<0.01$, Fig. 1). As illustrated in Figure 1, we clearly observe a concentration-dependent decrease in CD40 expressing cells starting at $3.125 \mu \mathrm{M}$ through $50 \mu \mathrm{M}$. As these compounds have been reported to be potentially cytotoxic, we also examined the level of microglial cell death in response to apigenin and luteolin treatment by LDH assay [52]. We discovered that apigenin and luteolin treatment only induced significant cell death at a $50 \mu \mathrm{M}$ concentration in 


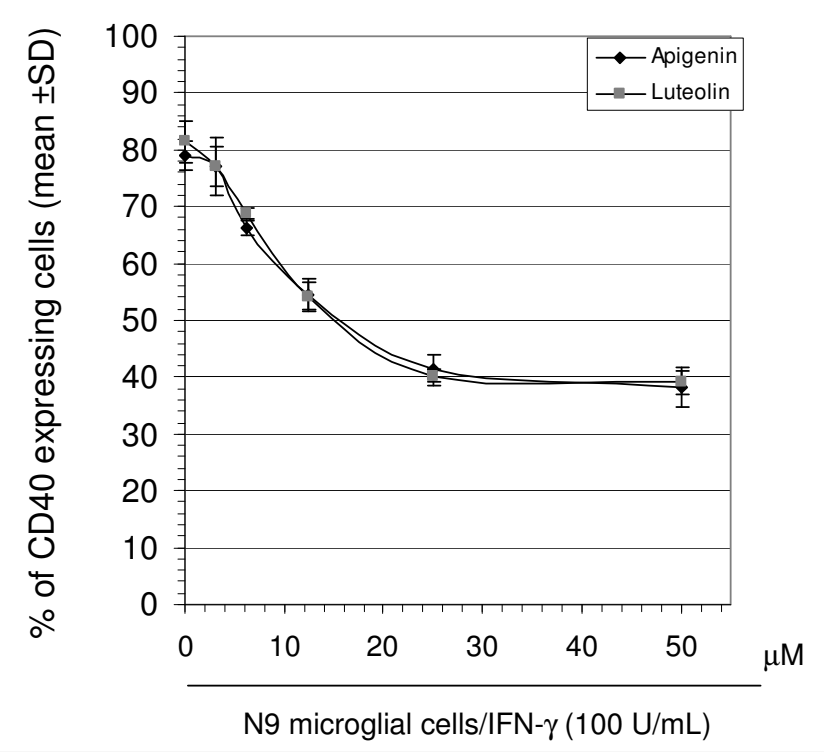

Figure I

Apigenin and luteolin reduce microglial CD40 expression induced by IFN- $\gamma$ in a concentration dependent manner. FACS analysis showed significant concentration dependent decreases in IFN- $\gamma$-induced CD40 expression by both apigenin and luteolin following $8 \mathrm{hrs}$. of co-treatment in N9 cells seeded in 6-well tissue-culture plates $(5 \times 105 /$ well). Data were represented as mean $\%$ of CD40 expressing cells (+/-SD). Results are representative of three independent experiments.

either N9 or primary microglial cells, which along with the data from Figure 1 suggested that $25 \mu \mathrm{M}$ may be the most efficacious concentration for regulating CD40 expression (Fig. 2C and 2D). Further, to determine if this reduction in CD40 expression continues through microglial activation, we treated both N9 and primary microglia cells with $25 \mu \mathrm{M}$ of apigenin or luteolin in the presence of a stimulatory amount of IFN- $\gamma$ as shown in figure 2 . Following FACS analysis, we once more found that both compounds significantly reduced CD40 expressing cells as compared to positive control in both cell lines ( $\mathrm{p}<$ 0.01 , Fig. 2A and 2B). Taken together, the above data suggests that apigenin and luteolin may be able to modulate microglial activation via CD40.

\section{Apigenin and luteolin oppose the effects of IFN- $\gamma$ ICD40 ligation on TNF- $\alpha$ and IL-6 production in N9 and murine- derived primary microglial cells}

To confirm the functional inhibition of CD40 in microglia, we treated both N9 and primary microglial cells with $25 \mu \mathrm{M}$ of either apigenin or luteolin in the presence of IFN- $\gamma$ and CD40 agonistic antibody. Following ELISA, we observed reductions in both secreted levels of TNF- $\alpha$ and IL-6 from flavonoid treated microglia as compared to positive control (Fig. 3). As shown in Figure 3, microglia co- treated with a stimulatory concentration of IFN- $\gamma$ and CD40 agonistic antibody simulates activation, thereby markedly elevating secretion of the archetypical proinflammatory cytokines TNF- $\alpha$ and IL- 6 and over negative control. However, in the presence of apigenin or luteolin TNF- $\alpha$ (Fig. 3A and 3B) and IL-6 (Fig. 3C and 3D) secretion is significantly reduced $(\mathrm{p}<0.01)$. Therefore, when considering the above data, it is apparent that both apigenin and luteolin modulate microglial activation and may prevent microglial-mediated inflammation by suppression of CD40 signaling.

\section{Apigenin and luteolin inhibit IFN- $\gamma$-induced STATI phosphorylation in N9 and murine-derived primary microglial cells}

To establish the mechanism whereby apigenin and luteolin decrease CD40 expression on the microglial cell surface, we investigated the upstream STAT1 signaling pathway. Both N9 and primary microglial cells were again treated with a $25 \mu \mathrm{M}$ concentration of either apigenin or luteolin in the presence of a stimulatory amount of IFN- $\gamma$. Following western blot analysis of cell lysates, we found a decrease in STAT1 signaling in both flavonoid treatments as compared to positive control (Fig. 4 and 5). Densitometric analyis of western blot data from N9 cell lysates in Figure 4B indicate significant reductions in STAT1 phosphorylation at serine residue $727(\mathrm{p}<0.01)$ with both apigenin and luteolin treatment. However, densitometric analysis of western blot data from primary microglial cells in Figure 5B and 5C reveals that apigenin significantly reduces STAT1 phosphorylation at tyrosine residue $701(\mathrm{p}$ $<0.01$ ) and luteolin significantly reduces STAT1 phosphorylation at serine residue $727(\mathrm{p}<0.01)$. Importantly, apigenin and luteolin treatment does not appear to affect holoprotein levels of STAT1 (Fig. 4A and 5A). Interestingly, we observed slight increases in STAT1 phosphorylation at serine 727 with flavonoid treatment alone, which may suggest these compounds have other unrelated, separate mechanisms. All in all, the above data suggest that apigenin and luteolin treatment regulates STAT1 at the level of phosphorylation and prevents the necessary signaling, in response to IFN- $\gamma$, required to induce CD40 expression.

\section{Discussion}

Compounds that modulate microglial activity would be indispensable tools in neurodegenerative disease therapy. Here, we identify two flavonoids, apigenin and luteolin, that reduce CD40 expression on microglia and elucidate a mechanism whereby these compounds may prevent harmful neuroinflammation. The transcription factor STAT1 has been a potential therapeutic target in our previous neurodegeneration research. It is becoming evident that STAT1 and related signaling proteins may be regulated by flavonoids. Apigenin and luteolin appear to affect 

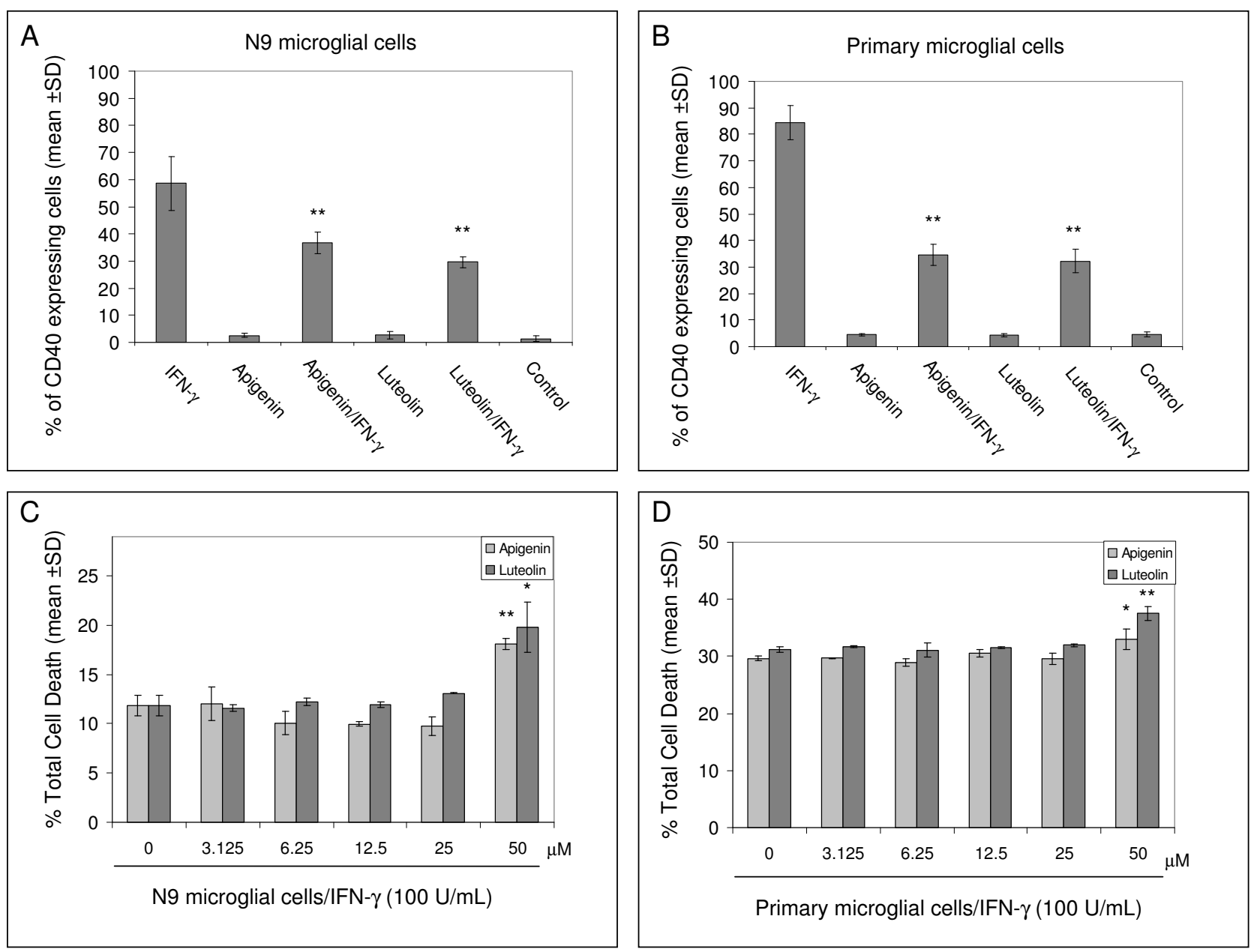

Figure 2

Apigenin and luteolin inhibit microglial CD40 expression induced by IFN- $\gamma$. N9 and murine-derived primary microglial cells were seeded in 6-well tissue-culture plates $(5 \times 105 /$ well) for FACS analysis and 24-well tissue-culture plates $(\mathrm{I} \times 105 /$ well) for LDH analysis in parallel. Cultured cells were co-treated with IFN- $\gamma(100 \mathrm{U} / \mathrm{mL})$ in the presence or absence of apigenin and luteolin $(25 \mu \mathrm{M})$ or treated with vehicle (I\% DMSO; control) for $8 \mathrm{hrs}$. For A and B, FACS analysis showed significant decreases by both apigenin and luteolin $(25 \mu \mathrm{M})$ in IFN- $\gamma$-induced CD40 expression in N9 cells and primary microglia. Data are represented as mean \% of CD40 expressing cells (+/- SD). For $C$ and D, cultured supernatants were collected and subjected to LDH assay as indicated. Data showed no significant increase in cell toxicity below a $50 \mu \mathrm{M}$ concentration of either flavonoid in both N9 or primary microglial cells. Data were represented as mean \% of total cell death as determined by LDH present during complete lysis (+/- SD). For A, B, C and D. Results are representative of three independent experiments. (*p < $0.05 ; * * p<$ $0.01)$.

the phosphorylation status of tyrosine 701 and serine 727 , which is required for STAT dimerization and maximal activation of transcription, respectively $[53,54]$. Even though we do observe slight increases in serine 727 STAT1 phosphorylation with flavonoid treatment alone (Fig. 4 and 5), it is likely that this phenomenon is related to these compounds' pro-apoptotic effects evidenced in tumor cell lines $[55,56]$. In a study by Elsisi and colleagues, apigenin was found to induce apoptosis in the BV-2 microglial cell line after 24 hours of incubation [57]. However, in our present study it is apparent that a $25 \mu \mathrm{M}$ concentration of apigenin may be at worst cytostatic towards both the primary derived and the "transformed/immortalized" N9 microglia with treatment times under 24 hours (Fig. 2C and 2D). It has been reported that regulation of apoptosis via STAT1 is dependent upon serine 727 phosphorylation [58-60]. In contrast, we observe significant reductions in serine 727 phosphorylation with apigenin in N9 micro- 

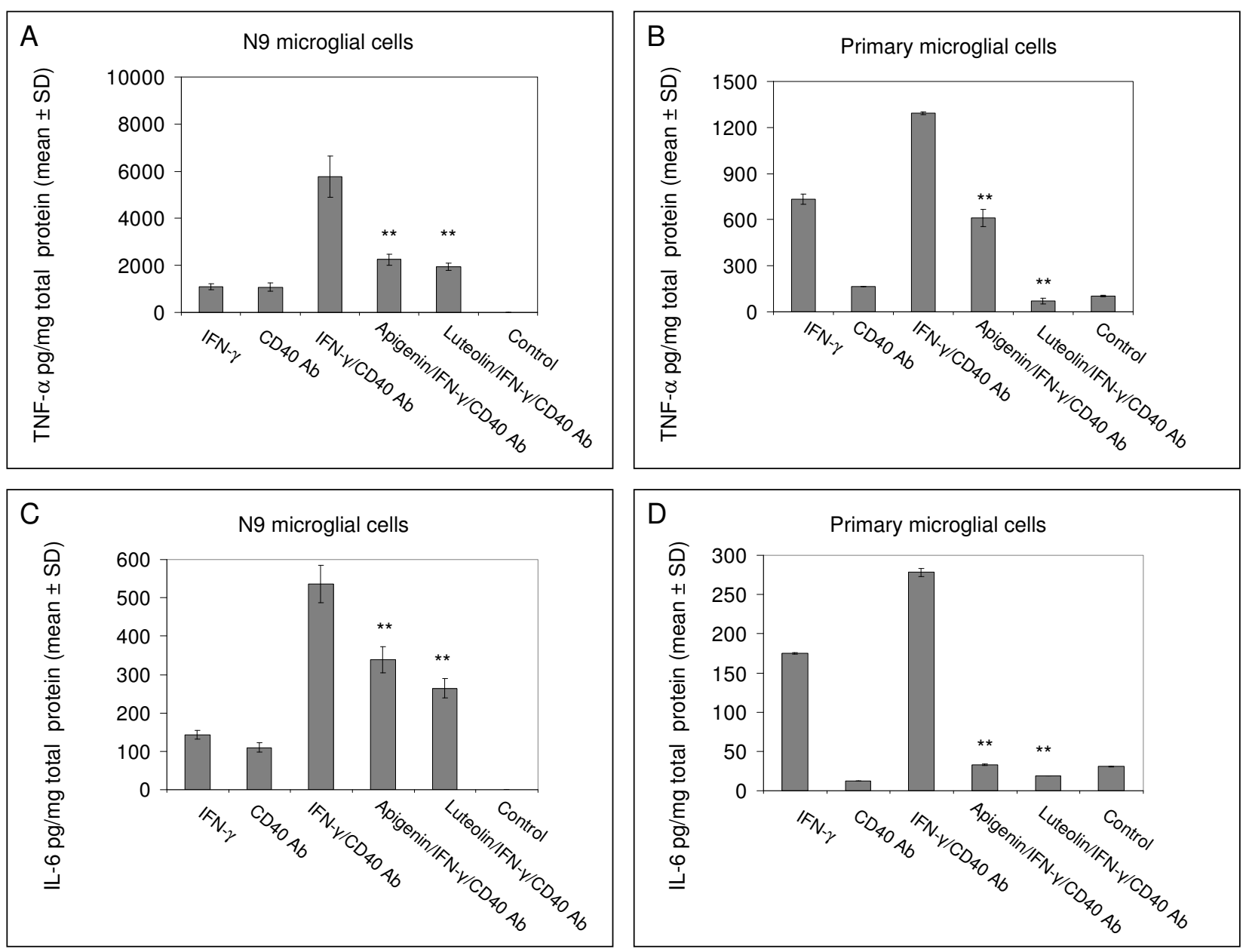

\section{Figure 3}

Apigenin and luteolin oppose the effects of IFN- $\gamma$ /CD40 ligation on TNF- $\alpha$ and IL-6 production in microglial cells. N9 and murine-derived primary microglial cells were seeded in 24 -well tissue-culture plates $\left(\mathrm{I} \times 10^{5} / \mathrm{well}\right)$ and cotreated with IFN- $\gamma(100 \mathrm{U} / \mathrm{mL})$ /agonistic anti-CD40 antibody (CD40 Ab; $2 \mu \mathrm{g} / \mathrm{mL})$ in the presence or absence of apigenin and luteolin $(25 \mu \mathrm{M})$ or treated with vehicle (I\% DMSO; control) for $12 \mathrm{hrs}$. Cell cultured supernatants were collected and subjected to cytokine ELISA as indicated. Data were represented as mean pg of each cytokine in mg of total cellular protein $(+/-$ $\mathrm{SD})$. Results are representative of three independent experiments. $\left({ }^{* *} p<0.0 \mathrm{I}\right)$.

glia and luteolin in both N9 and primary microglia in the presence of IFN- $\gamma$ (Fig. 4 and 5). Therefore, it may be likely that the pro-apoptotic/anti-carcinogenic and immunomodulatory mechanisms of these flavonoids interface at the level of STAT1, a molecule qualified to function in this capacity. Still, distinct differences between these mechanisms may be dependent on the microenvironment and remain to be established.

While phosphorylation of tyrosine residue 701 on STAT1 is an event essential for STAT dimerizaton and translocation, it neither is a required precursor to serine 727 phosphorylation nor a mediator of apoptosis [58-60]. However, it appears to be as necessary as serine 727 phos- phorylation for STAT1 signaling as apigenin effectively reduces CD40 expression in the presence of IFN- $\gamma$ in primary microglia (Fig. 2B). Interestingly, we find that apigenin appears to regulate tyrosine 701 phosphorylation, but not serine 727 phosphorylation, of STAT1 in primary microglia, which suggests that it has a distinct target/ mechanism separate from that of luteolin. Furthermore, these mechanistic differences underscore the differences inherent between primary derived and N9 microglia.

The ability of these flavonoids to regulate CD40-CD40L interaction and consequently pro-inflammatory mediators may be useful in the treatment of many inflammatory diseases. Nonetheless, inflammation in neurodegenera- 

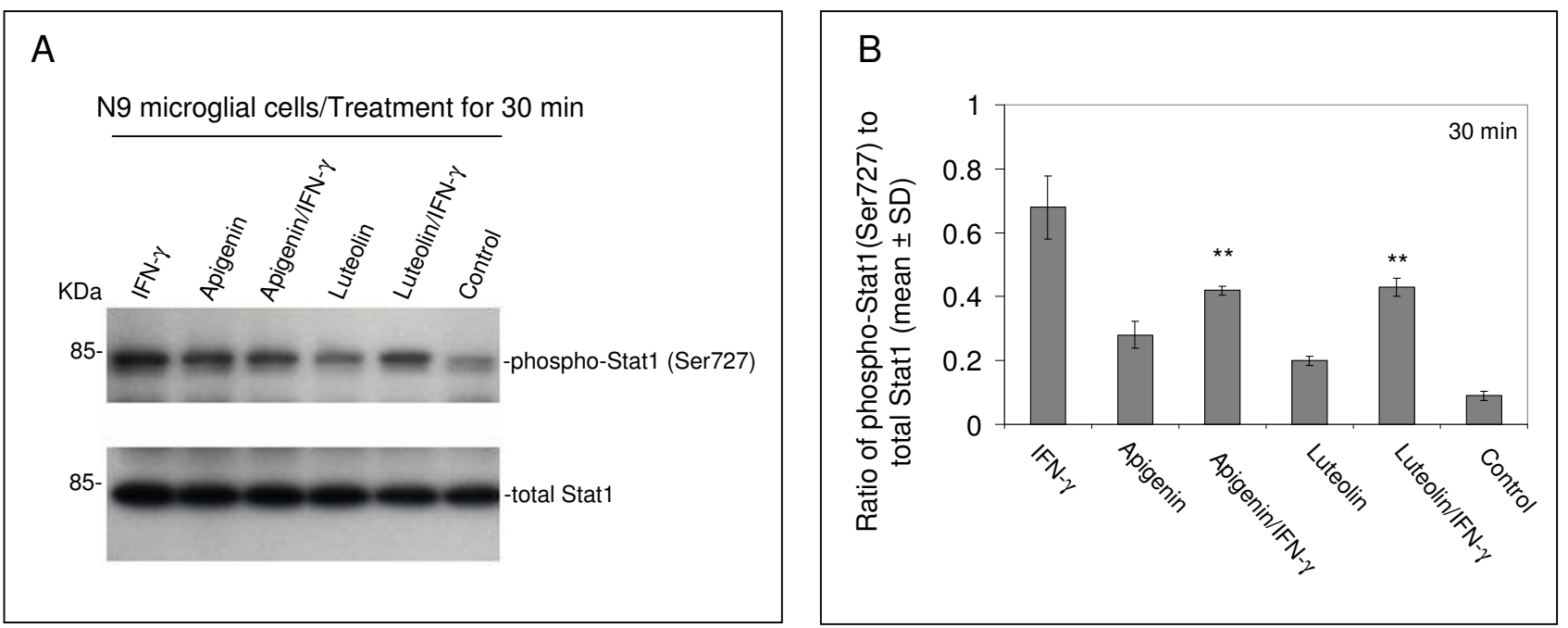

Figure 4

Apigenin and luteolin oppose IFN- $\gamma$-induced phosphorylation of STATI in N9 microglial cells. N9 murine microglial cells were seeded in 24-well tissue-culture plates $(I \times 105 /$ well) and treated with IFN- $\gamma(100 \mathrm{U} / \mathrm{mL})$ in the presence or absence of apigenin and luteolin $(25 \mu \mathrm{M})$ or treated with vehicle (I\% DMSO; control) for 30 mins. Cell lysates were prepared from these cells and subjected to western immunoblotting using anti-phospho-STATI (Ser727) and anti-total STATI antibody as indicated. For B, data are represented as mean ratios of phospho-Stat I (Ser727) to total Stat I (+/- SD) from densitometric analyses. Results are representative of three independent experiments. (**p $<0.0 \mathrm{I})$.

tive disease represents a specific immunoprofile, involving discrete units made up of glial cells and neurons. Complete abolishment of CD40-CD40L interactions between microglia, astrocytes, and neurons may prove to be hazardous, as we have previously shown that ligation of CD40 protected neuronal cells from nerve growth factor- $\beta$ (NGF- $\beta$ ) or serum withdrawal-induced injury and promoted differentiation [61]. Rather, modulation of immune reactions in CNS would appear to be the most appropriate course of action for treating neurodegenerative disease. While it would be quite difficult to achieve this modulation with conventional drugs, flavonoids appear to be uniquely fitted to this task as we observe their ability to affect multiple converging signaling pathways. For instance, apigenin and luteolin appear to regulate serine 727 phosphorylation of STAT1 at levels that are potentially conducive to apoptosis, all the while keeping a damper on levels in the presence of IFN- $\gamma$ (Fig. 4 and 5). It is in this way that these compounds are essentially promoters of homeostasis.

It is quite clear from both the present study and previous research that apigenin and luteolin are potentially safe and effective immunomodulators, although their direct molecular targets have not been identified. What seems to be apparent is that these compounds prevent STAT1 signaling, which consequently may prevent the transcription of its target genes. Even as these compounds affect STAT1, it is more likely that upstream kinases or phosphatases are directly involved. Phosphatidylinositol 3-kinase (PI3K), its effector kinase Akt, JAK1, and JAK2 are all required for phosphorylation of both serine 727 and tyrosine 701 of STAT1 [62]. Accordingly, these kinases are all potential molecular targets of apigenin and luteolin. Previous reports also suggest that similar flavonoids mediate their effects through protein tyrosine phosphatases. Furthermore, CD45, a protein tyrosine phosphatase important for immune regulation and function, has been identified as an upstream regulator of STAT1 signaling via dephosphorylation of JAKs [63]. In light of these findings, it may be important to evaluate the effects of these flavonoids on other potential immunoregulatory signaling molecules to better ascertain both safety and efficacy.

While a major limitation in the use of these flavonoids as immunomodulators or anti-inflammatory agents is their low bioavailability, apigenin, in particular, may hold some promise as a suitable therapeutic agent. Recent $\mathrm{pK}$ studies suggest that apigenin exhibits a slow metabolism, absorption, and elimination phase (92 hours in rats) [6466]. Moreover, in one human pK study, apigenin was also found to significantly reduce measures of oxidative stress in blood [67]. Like many aglycone forms of flavonoids, apigenin and luteolin potentially reach their molecular targets by passive diffusion through cell membranes. This means of cellular uptake may explain the onset $(<30$ 

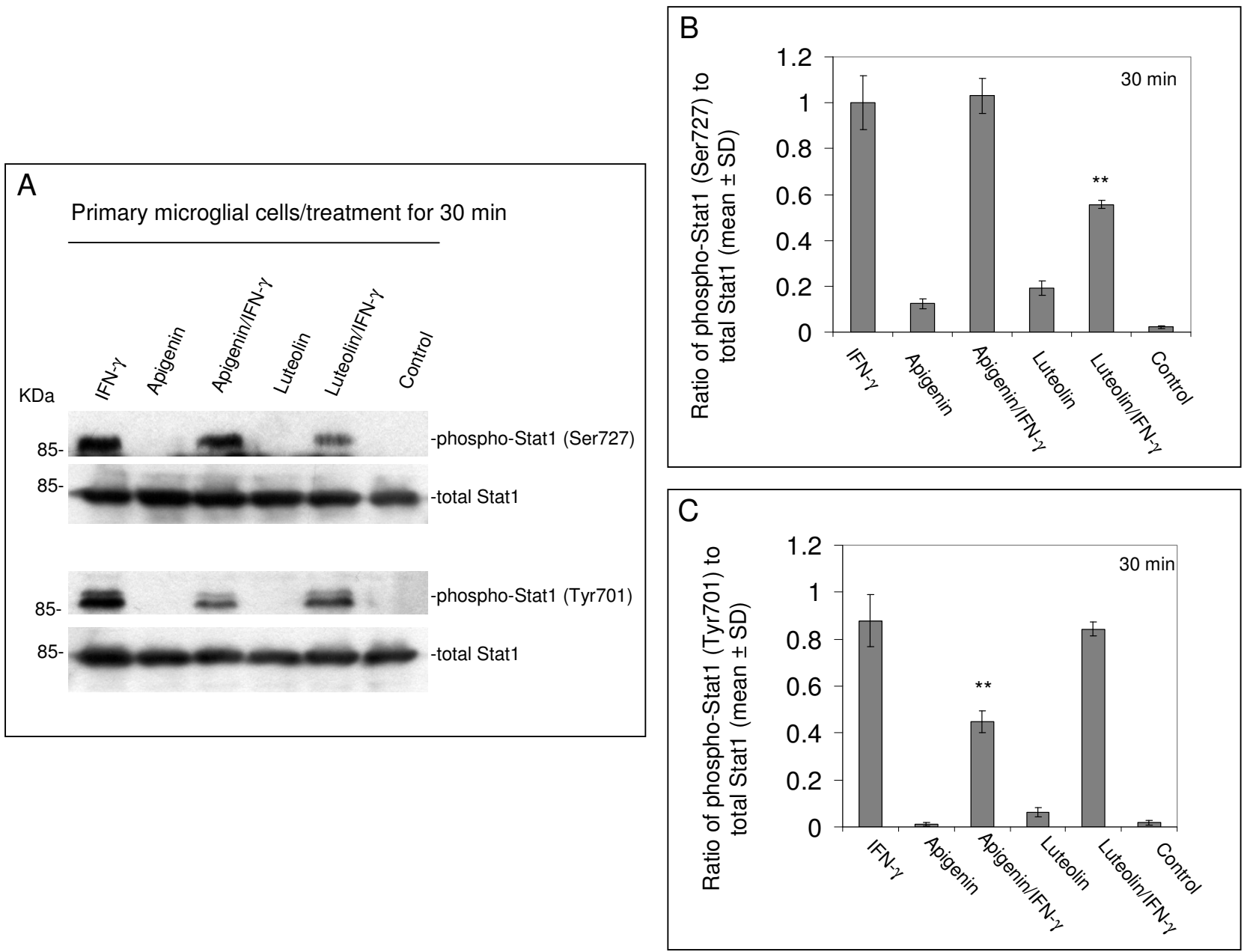

\section{Figure 5}

Apigenin and luteolin oppose IFN- $\gamma$-induced phosphorylation of STATI in murine-derived primary microglial cells. Murine-derived primary microglial cells were seeded in 24-well tissue-culture plates $\left(\mathrm{I} \times 10^{5} /\right.$ well) and treated with IFN$\gamma(100 \mathrm{U} / \mathrm{mL})$ in the presence or absence of apigenin and luteolin $(25 \mu \mathrm{M})$ or treated with vehicle (I\% DMSO; control) for 30 mins. Cell lysates were prepared from these cells and subjected to western immunoblotting using anti-phospho-STATI

(Ser727 or Tyr70I) and anti-total STATI antibody as indicated. For B and C, data are represented as mean ratios of phosphoStat I (Ser727 or Tyr70I) to total Stat I (+/- SD) from densitometric analyses. Results are representative of three independent experiments. (**p $<0.01)$.

mins) of STAT1 inactivation as we observed following apigenin and luteolin treatment (Fig. 3). Despite the possibility of sustainable therapeutic concentrations, future work with these compounds will certainly need to address blood-brain-barrier permeability.

\section{Conclusion}

In summary, flavonoids apigenin and luteolin may prevent microglial-mediated inflammation by modulating the induction of CD40 in response IFN $-\gamma$. This decrease in expression modulates CD40-40L interactions, which are critical to microglial activation. Apigenin and luteolin's mechanism of action appears to be targeted at regulating STAT1 activation. These studies may lay the foundation for the development of neurodegenerative disease modifying therapies focused on preventing harmful inflammation while maintaining proper glia-neuron interactions.

\section{Abbreviations}

A $\beta$ : beta-amyloid; AD: Alzheimer's disease; ANOVA: analysis of variance; CD40L: CD40 ligand; CNS: central nervous system; FACS: fluorescence activated cell sorting; INF$\gamma$ : interferon gamma; IL-6: interleukin-6; JAK/STAT: janus kinase/signal transducer and activator of transcription; 
LDH: lactate dehydrogenase; NGF- $\beta$ : nerve growth factor beta; ROS: reactive oxygen species; TNF- $\alpha$ : tumor necrosis factor alpha.

\section{Competing interests}

PB and PRS are cofounders, and RDS and JT are scientific consultants for Natura Therapeutics, Inc. (Tampa, FL), a USF spin-out company. Natura Therapeutics manufactures a botanically derived dietary supplement that contains both apigenin and luteolin.

\section{Authors' contributions}

KR assisted in the experimental design, analyzed the data, and completed the manuscript and figures. JE assisted in the experimental design, conducted LDH and Western blot experiments, and assisted in the completion of the manuscript. YB assisted in the experimental design and conducted FACS experiments. PB and PS assisted in the experimental design. RDS and JT conceived and directed the project. All authors read and approved the final manuscript.

\section{Acknowledgements}

This work was supported in part by grants from the Johnnie B. Byrd, Sr. Alzheimer's Center \& Research Institute (RDS and JT) and, in part, from grants R2IAG03 037 (RDS) and POI044I8P2 (JT) from the National Institute on Aging.

\section{References}

I. Eikelenboom P, Bate C, Van Gool WA, Hoozemans J, Rozemuller JM, Veerhuis R, Williams A: Neuroinflammation in Alzheimer's disease and prion disease. Glia 2002, 40:232-239.

2. Garden GA: Microglia in human immunodeficiency virus-associated neurodegeneration. Glia 2002, 40:240-25I.

3. Schubert P, Morino T, Miyazaki H, Ogata T, Nakamura Y, Marchini C, Ferroni S: Cascading glia reactions: a common pathomechanism and its differentiated control by cyclic nucleotide signaling. Ann N Y Acad Sci 2000, 903:24-33.

4. Tan J, Town T, Paris D, Placzek A, Parker T, Crawford F, Yu H, Humphrey J, Mullan M: Activation of microglial cells by the CD40 pathway: relevance to multiple sclerosis. Neuroimmunol 1999, 97:77-85.

5. Hall ED, Oostveen JA, Gurney ME: Relationship of microglial and astrocytic activation to disease onset and progression in a transgenic model of familial ALS. Glia 1998, 23:249-256.

6. Barger SW, Harmon AD: Microglial activation by Alzheimer amyloid precursor protein and modulation by apolipoprotein E. Nature 1997, 388:878-88।.

7. Raine C: Multiple sclerosis: immune system molecule expression in the central nervous system. J Neuropathol Exp Neurol 1994, 53:328-337.

8. Dickson DW, Lee SC, Mattiace LA, Yen SH, Brosnan C: Microglia and cytokines in neurological disease, with special reference to AIDS and Alzheimer's disease. Glia 1993, 7:75-83.

9. Kawamata T, Akiyama H, Yamada T, McGeer PL: Immunologic reactions in amyotrophic lateral sclerosis brain and spinal cord tissue. Am J Pathol 1992, 140:691-707.

10. Yamada T, McGeer PL, McGeer EG: Relationship of complement-activated oligodendrocytes to reactive microglia and neuronal pathology in neurodegenerative disease. Dementia |99|, 2:7|-77.

II. McGeer PL, Itagaki S, Boyes BE, McGeer EG: Reactive microglia are positive for HLA-DR in the substantia nigra of Parkinson's and Alzheimer's disease brains. Neurology 1988, 38: $|285-129|$.
12. Xie Z, Wei M, Morgan TE, Fabrizio P, Han D, Finch CE, Longo VD: Peroxynitrite mediates neurotoxicity of amyloid $\beta$-peptide I42-and lipopolysaccharide-activated microglia. J Neurosci 2002, 22:3484-3492.

13. McGuire SO, Ling ZD, Lipton JW, Sortwell CE, Collier TJ, Carvey PM: Tumor necrosis factor alpha is toxic to embryonic mesencephalic dopamine neurons. Exp Neurol 200I, 169:2 19-230.

14. Jeohn G-H, Kong L-Y, Wilson B, Hudson P, Hong J-S: Synergistic neurotoxic effects of combined treatments with cytokines in murine primary mixed neuron/glia cultures. J Neuroimmuno 1998, 85:I-10.

15. Chao CC, Hu S, Ehrlich L, Peterson PK: Interleukin-I and tumor necrosis factor- $\alpha$ synergistically mediate neurotoxicity: involvement of nitric oxide and of $\mathbf{N}$-methyl-D-aspartate receptors. Brain Behav Immun 1995, 9:355-365.

16. Boje KM, Arora PK: Microglial-produced nitric oxide and reactive nitrogen oxides mediate neuronal cell death. Brain Res 1992, 587:250-6.

17. Chao CC, Hu S, Molitor TW, Shaskan EG, Peterson PK: Activated microglia mediate neuronal cell injury via a nitric oxide mechanism. J Immunol 1992, 149:2736-2741.

18. Streit WJ: Microglia and neuroprotection: implications for Alzheimer's disease. Brain Res Brain Res Rev 2005, 48:234-9.

19. Alderson MR, Armitage RJ, Tough TW, Strockbine L, Fanslow WC, Spriggs MK: CD40 expression by human monocytes: regulation by cytokines and activation of monocytes by the ligand for CD40. J Exp Med 1993, I 78:669-74.

20. van Kooten C, Banchereau J: CD40-CD40 ligand. J Leukoc Biol 2000, 67:2-17.

21. Grewal IS, Flavell RA: CD40 and CDI54 in cell-mediated immunity. Annu Rev Immunol 1998, 16: I II-I35.

22. Nguyen VT, Walker WS: Benveniste EN, Post-transcriptional inhibition of CD40 gene expression in microglia by transforming growth factor-beta. Eur J Immunol 1998, 28:2537-2548.

23. Boehm U, Klamp T, Groot M, Howard JC: Cellular responses to interferon-gamma. Annu Rev Immunol 1997, I 5:749-795.

24. Seder, Paul RA, Seder, Paul WE: Acquisition of lymphokine-producing phenotype by CD4+ T cells. Annu Rev Immunol 1994, I 2:635-673.

25. Nguyen VT, Benveniste EN: Involvement of STAT-I and ets family members in interferon-gamma induction of CD40 transcription in microglia/macrophages. J Biol Chem 2000, 275:23674-84.

26. Leonard WJ, O'Shea Jj: Jaks and STATs: biological implications. Annu Rev Immunol 1998, 16:293-322.

27. Townsend KP, Town T, Mori T, Lue LF, Shytle D, Sanberg PR, Morgan $D$, Fernandez F, Flavell RA, Tan J: CD40 signaling regulates innate and adaptive activation of microglia in response to amyloid beta-peptide. Eur J Immunol 2005, 35:90I-I0.

28. Townsend KP, Shytle DR, Bai Y, San N, Zeng J, Freeman M, Mori T, Fernandez F, Morgan D, Sanberg P, Tan J: Lovastatin modulation of microglial activation via suppression of functional CD40 expression. J Neurosci Res 2004, 78: 167-76.

29. Dai Q, Borenstein AR, Wu Y, Jackson JC, Larson EB: Fruit and vegetable juices and Alzheimer's disease: the Kame Project. Am J Med 2006, I 1 9:75।-9.

30. Genkinger JM, Platz EA, Hoffman SC, Comstock GW, Helzlsouer KJ: Fruit, vegetable, and antioxidant intake and all-cause, cancer, and cardiovascular disease mortality in a communitydwelling population in Washington County, Maryland. Am J Epidemiol 2004, 160:1223-33.

3I. Laurin D, Masaki KH, Foley DJ, White LR, Launer LJ: Midlife Dietary Intake of Antioxidants and Risk of Late-Life Incident Dementia: The Honolulu-Asia Aging Study. Am J Epidemiol 2004, 1 59:959-967.

32. Bastianetto $S:$ Red wine consumption and brain aging. Nutrition 2002, I 8:432-3.

33. Sun AY, Simonyi A, Sun GY: The "French Paradox" and beyond: neuroprotective effects of polyphenols. Free Radic Biol Med 2002, 32:3|4-8.

34. Sampson L, Rimm E, Hollman PC, de Vries JH, Katan MB: Flavonol and flavone intakes in US health professionals. J Am Diet Assoc 2002, 102:14|4-20.

35. Nielsen SE, Young JF, Daneshvar B, Lauridsen ST, Knuthsen P, Sandstrom B, Dragsted LO: Effect of parsley (Petroselinum crispum) intake on urinary apigenin excretion, blood antioxidant 
enzymes and biomarkers for oxidative stress in human subjects. BrJ Nutr 1999, 81:447-55.

36. van Acker SA, Berg DJ van den, Tromp MN: Structural aspects of antioxidant activity of flavonoids. Free Rad Biol Med 1996, 20:33I-342.

37. Saija A, Scalese M, Lanza M, Marzullo D, Bonina F: Flavonoids as antioxidant agents: importance of their interaction with biomembranes. Free Rad Biol Med 1995, 19:48I-486.

38. Kanadaswami C, Lee LT, Lee PP, Hwang J], Ke FC, Huang YT, Lee MT: The antitumor activities of flavonoids. In Vivo 2005, 19:895-909.

39. Ren W, Qiao Z, Wang H, Zhu L, Zhang L: Flavonoids: promising anticancer agents. Med Res Rev 2003, 23:519-34.

40. Ferrandiz ML, Gil B, Sanz MJ: Effect of bakuchiol on leukocyte functions and some inflammatory responses in mice. J Pharm Pharmacol 1996, 48:975-80.

4I. Friesenecker B, Tsai AG, Allegra C, Intaglietta M: Oral administration of purified micronized flavonoid fraction suppresses leukocyte adhesion in ischemia-reperfusion injury: in vivo observations in the hamster skin fold. Int J Microcirc Clin Exp 1994, 14:50-5

42. Bennett JP, Gomperts BD, Wollenweber E: Inhibitory effects of natural flavonoids on secretion from mast cells and neutrophils. Arzneimittelforschung 198I, 31:433-7.

43. Yoon MS, Lee JS, Choi BM, Jeong YI, Lee CM, Park JH, Moon Y, Sung SC, Lee SK, Chang YH, Chung HY, Park YM: Apigenin inhibits immunostimulatory function of dendritic cells: Implication of immunotherapeutic adjuvant. Mol Pharmacol 2006, 70(3): 1033-1044.

44. Hirano T, Arimitsu J, Higa S, Naka T, Ogata A, Shima Y, Fujimoto M, Yamadori T, Ohkawara T, Kuwabara Y, Kawai M, Kawase I, Tanaka T: Luteolin, a flavonoid, inhibits CD40 ligand expression by activated human basophils. Int Arch Allergy Immunol 2006, 40: I 50-6.

45. Ueda $\mathrm{H}$, Yamazaki C, Yamazaki M: A hydroxyl group of flavonoids affects oral anti-inflammatory activity and inhibition of systemic tumor necrosis factor-alpha production. Biosci Biotechnol Biochem 2004, 68: |19-25.

46. Smolinski AT, Pestka JJ: Modulation of lipopolysaccharideinduced proinflammatory cytokine production in vitro and in vivo by the herbal constituents apigenin (chamomile), ginsenoside $R \mathbf{b}(\mathrm{I})$ (ginseng) and parthenolide (feverfew). Food Chem Toxicol 2003, 41: I381-90.

47. Raso GM, Meli R, Di Carlo G, Pacilio M, Di Carlo R: Inhibition of inducible nitric oxide synthase and cyclooxygenase-2 expression by flavonoids in macrophage J774A.I. Life Sci 200I, 68:92I-3I

48. Liang YC, Tsai SH, Tsai DC, Lin-Shiau SY, Lin JK: Suppression of inducible cyclooxygenase and nitric oxide synthase through activation of peroxisome proliferator-activated receptorgamma by flavonoids in mouse macrophages. FEBS Lett 200I, 496: $12-8$.

49. Gerritsen ME, Carley WW, Ranges GE, Shen CP, Phan SA, Ligon GF, Perry CA: Flavonoids inhibit cytokine-induced endothelial cell adhesion protein gene expression. Am J Pathol 1995, 147:278-92.

50. Tan J, Town T, Saxe M, Paris D, Wu Y: Mullan M, Ligation of microglial CD40 results in p44/42 mitogen-activated protein kinase-dependent TNF-alpha production that is opposed by TGF-beta I and IL-10. J Immunol 1999, 163:66|4-2I.

5I. Corradin SB, Mauël J, Donini SD, Quattrocchi E, Ricciardi-Castagnoli $P$ : Inducible nitric oxide synthase activity of cloned murine microglial cells. Glia 1993, 7:255-62.

52. Matsuo M, Sasaki N, Saga K, Kaneko T: Cytotoxicity of flavonoids toward cultured normal human cells. Biol Pharm Bull 2005, 28:253-9.

53. Kovarik P, Mangold M, Ramsauer K: Specificity of signaling by STATI depends on SH2 and C-terminal domains that regulate Ser727 phosphorylation, differentially affecting specific target gene expression. EMBO / 200I, 20:91-100

54. Goh KC, Haque SJ, Williams BR: p38 MAP kinase is required for STATI serine phosphorylation and transcriptional activation induced by interferons. $E M B O \mid$ । 1999, I 8:560I-8.

55. Chen D, Daniel KG, Chen MS, Kuhn DJ, Landis-Piwowar KR, Dou QP: Dietary flavonoids as proteasome inhibitors and apoptosis inducers in human leukemia cells. Biochem Pharmacol 2005 , 69:1421-32.
56. Zheng PW, Chiang LC, Lin CC: Apigenin induced apoptosis through p53-dependent pathway in human cervical carcinoma cells. Life Sci 2005, 76:1367-79.

57. Elsisi NS, Darling-Reed S, Lee EY, Oriaku ET, Soliman KF: Ibuprofen and apigenin induce apoptosis and cell cycle arrest in activated microglia. Neurosci Lett 2005, 375:91-6.

58. Townsend PA, Scarabelli TM, Davidson SM, Knight RA, Latchman DS Stephanou A: STAT-I interacts with p53 to enhance DNA damage-induced apoptosis. J Biol Chem 2004, 279:58I I-20.

59. Stephanou A, Scarabelli TM, Brar BK, Nakanishi Y, Matsumura M, Knight RA, Latchman DS: Induction of apoptosis and Fas receptor/Fas ligand expression by ischemia/reperfusion in cardiac myocytes requires serine 727 of the STAT-I transcription factor but not tyrosine 70I. J Biol Chem 200I, 276:28340-7.

60. Kumar A, Commane M, Flickinger TW, Horvath CM, Stark GR Defective TNF-alpha-induced apoptosis in STATI-null cells due to low constitutive levels of caspases. Science 1997, 278:1630-2.

61. Tan J, Town T, Mori T, Obregon D, Wu Y, DelleDonne A, Rojiani A, Crawford F, Flavell RA, Mullan M: CD40 is expressed and functional on neuronal cells. EMBO J 2002, $21: 643-52$.

62. Nguyen H, Ramana CV, Bayes J, Stark GR: Roles of phosphatidylinositol 3-kinase in interferon-gamma-dependent phosphorylation of STATI on serine 727 and activation of gene expression. J Biol Chem 200I, 276:3336I-8.

63. Irie-Sasaki J, Sasaki T, Matsumoto W, Opavsky A, Cheng M, Welstead G, Griffiths E, Krawczyk C, Richardson CD, Aitken K, Iscove N, Koretzky G, Johnson P, Liu P, Rothstein DM, Penninger JM: CD45 is a JAK phosphatase and negatively regulates cytokine receptor signaling. Nature 200I, 409:349-54.

64. Manach C, Williamson G, Morand C, Scalbert A, Remesy C: Bioavailability and bioefficacy of polyphenols in humans. I. Review of 97 bioavailability studies. Am J Clin Nutr 2005, $8 \mathrm{I}: 230 \mathrm{~S}-42 \mathrm{~S}$.

65. Gradolatto A, Basly JP, Berges R, Teyssier C, Chagnon MC, Siess MH, Canivenc-Lavier MC: Pharmacokinetics and metabolism of apigenin in female and male rats after a single oral administration. Drug Metab Dispos 2005, 33:49-54.

66. Gradolatto A, Canivenc-Lavier MC, Basly JP, Siess MH, Teyssier C: Metabolism of apigenin by rat liver phase $I$ and phase ii enzymes and by isolated perfused rat liver. Drug Metab Dispos 2004, 32:58-65.

67. Li LP, Jiang HD: Determination and assay validation of luteolin and apigenin in human urine after oral administration of tablet of Chrysanthemum morifolium extract by HPLC. J Pharm Biomed Anal 2006, 4 I:26 I-5.

Publish with Bio Med Central and every scientist can read your work free of charge

"BioMed Central will be the most significant development for disseminating the results of biomedical research in our lifetime. "

Sir Paul Nurse, Cancer Research UK

Your research papers will be:

- available free of charge to the entire biomedical community

- peer reviewed and published immediately upon acceptance

- cited in PubMed and archived on PubMed Central

- yours - you keep the copyright
BioMedcentral 